\title{
ADAPTATION OF ARCHITECTURAL STYLE TO PRESERVE CULTURAL HERITAGE BUILDING Case Study: Vihara Dewi Welas Asih-Cirebon
}

\author{
Nurtati Soewarno \\ Department Architecture, Institut Teknologi Nasional, Bandung, Indonesia \\ corresponding author: nurtati@itenas.ac.id \\ Received: 21 April \\ 2020 \\ Revised: 27 April \\ 2020 \\ Article History: \\ Accepted: 28 Apri; $\quad$ Available online: 30 April \\ 2020 \\ 2020
}

\begin{abstract}
Indonesia is an archipelago that is located between two continents, Asia and Australia, also between two oceans, the Pacific and the Indian ocean. This prospers in commercial activity. Because of the location, coastal cities are easier to reach, a foreigner that drops in have a significant impact on these cities, for example, Cirebon, a coastal city that lies in the northeast part of West Jawa. Various foreigners that drop in and also stay in Cirebon could be seen by the heritage, one of them is the Vihara Dewi Welas Asih. The temple as a house of worship for Konghucu religion is easy to be known by the color and Chinese specific architectural style. The city development pushes to changes, as to the Vihara Dewi Welas Asih, renovation and additional buildings are inevitable. This paper is to study the architectural style applied to the additional buildings surrounding the temple. By observation, the architectural style of the new building is recognized, also how the context of the new building compared to the temple. It is expected that the new architectural style will be in harmony with the Vihara Dewi Welas Asih architectural style. It is also expected that intervention by the Local Government in organizing the alteration so the Cultural Heritage area is well maintained, become a tourist destination site giving a positive impact to the continuity of the Cultural Heritage building in Cirebon city.
\end{abstract}

Keywords: architectural style adaptation, Vihara Dewi Welas Asih, Cultural Heritage Building

\section{Introduction}

Cirebon is one of the cities in the North Beach of West Java that possesses a high historical and cultural values. Cirebon started from a small village (in the 15th century) named Muara Jati. The strategic location makes this village frequently visited by foreign ships that intend to trade with residents, among them are Arabian, European, and Chinese. The existence of Chinese people is proven by artifacts that could be seen and also still used, the worship building called Klenteng.

The Klenteng Tiao Kak Sie or Vihara Dewi Welas Asih is the oldest("Mengintip Sejarah Vihara Dewi Welas Asih, Klenteng Tertua di Kota CirebonNo Title," n.d.). This temple lies in the Cirebon coastal area which later on mingles with office buildings that were built in the Dutch Colonial era. Today the Temple and Chinese architectural buildings are settled as Cultural Heritage Building through the Cirebon Mayors decision number 19 the year 2001 about Protection and Preservation of the district and Cultural Heritage Buildings in the Cirebon city. Besides that, these buildings according to Indonesian Regulations number 11 the year 2010 that Cultural Heritage must be maintained(Binbangkum, 2010).

Along with time, the flock and the activity of the temple grows, so additional rooms or buildings are needed. According to Brollin (Brolin, 1980) the new building layout must be able to strengthen and expand the characteristic of environmental management, or at least maintain the existing pattern. Contextual design is a useful development tool because making it possible for the building mentioned there, in this case, the Vihara Dewi Welas Asih to be maintained in a good context.

By studying history, the picture of Vihara Dewi Welas Asih's architectural style and the initial surroundings could be obtained. Meanwhile, to find out the current condition, field observation is needed, to claim accurate data. 
Today the descendant of the Chinese persons have a different outlook, custom, and culture from their predecessor, so the temple is no more as a worship building but as a cultural heritage. The shrinkage of the congregation will influence the building condition because for maintenance a lot of funds are required, so for renovation or additional building, that must be done professionally to keep the authenticity of Vihara Dewi Welas Asih as a Cultural Heritage.

\section{Research Method}

Starting with literature studying about the history of the establishment of Cirebon city and the arrival of the Chinese to Cirebon, data regarding the construction of the Vihara Dewi Welas Asih that formerly was named Klenteng Tio Kak Sie. Besides the picture of the environmental conditions around the temple as a commercial center in the Cirebon coast could be obtained. This was conducted to determine the original architectural style of the temple. Field observations were carried out by photographing, filming, measuring, and redrawing of the temple and surrounding area. This was conducted to determine the present architecture style of the temple and additional building at the complex of Vihara Dewi Welas Asih. Interviews with people who take care of temple were also conducted to have further information regarding the development of Vihara Dewi Welas Asih

\section{Discussion of result}

\subsection{The History of the arrival of the Chinese to Cirebon}

Chinese village establishment is estimated around the year 1415 when Admiral Cheng Ho landed in Muara Jati port. The purpose of their arrival was to trade and during that time, since this was a large group with many members, they spread to several areas including Kuningan area with Toa Lang as the center, on the seashore today named Talang steet.

The oldest Klenteng Hok Keng Tong or Vihara Dharma Sukha was discovered in Plered, near the market, but the old building could not be found. The establishment of this temple was estimated in the year 1386. Meanwhile, the Wihara Dewi Welas Asih or Klenteng Tio Kak Sie was established in the year 1559 and is the oldest temple in Cirebon city, lies in the coast not far from Toa Lang("Mengintip Sejarah Vihara Dewi Welas Asih, Klenteng Tertua di Kota CirebonNo Title," n.d.).

The year 1540 the Chinese village became larger when princess Ong Tien landed in Cirebon and got married to Sunan Gunung Jati. The number of followers was very large and those who didn't go back to their country, serve, assimilate, and married with the indigenous even built Klenteng Hok Tek Ceng Sin in Jamblang village, about $10 \mathrm{~km}$ from Cirebon. The temple name, later on, changes into Wihara Dharma Rakhita(Lia, n.d.).

After the marriage of Princess Ong Tien with Sunan Gunung Jati, many Chinese enter Cirebon city and settle in the Kanoman Market area. In the year 1984 in this area, the Klenteng Boen San Tong was established, later become Vihara Pemancar Keselamatan. Until today this area becomes a trading area of China town leaving some Chinese architecture style buildings.

\subsection{Chinese Architecture Style}

According to Kohl, 1984 (Kohl, 1984) the main characteristic of Chinese Architecture in Asia is :

1. Courtyard; the courtyard is a basic pattern use for residences. In the China town areas in Indonesia, because of the limited lot space, the courtyard is generally in the shape of a hole to put in the sunshine during day time and as air ventilation. Usually, in the shape of a wide terrace, it could also function as an indoor garden. For large lots, the courtyard could also be in the shape of a yard between the main gate and main building, function as an outer garden. 

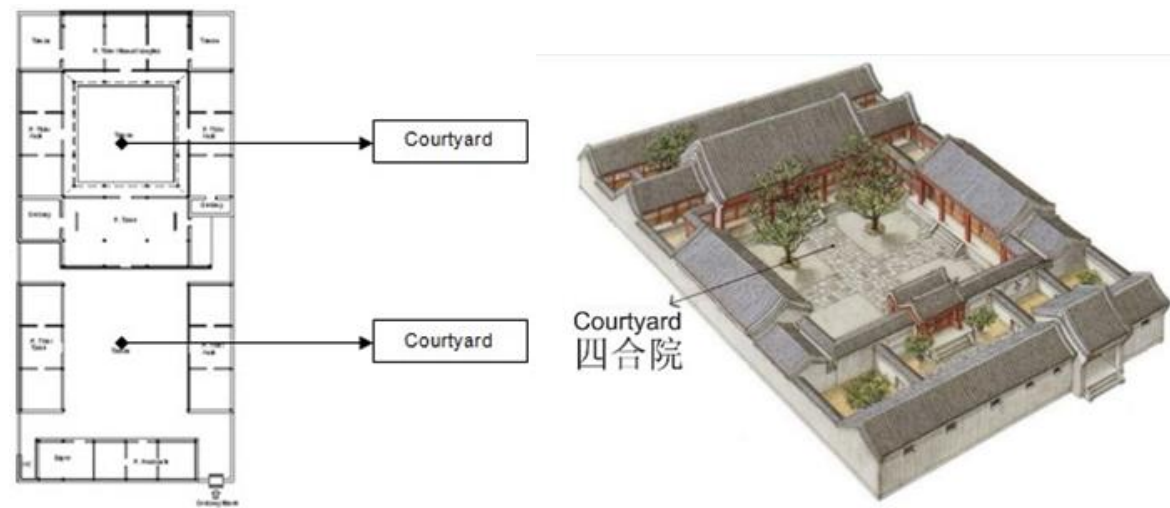

Figure 1: Courtyard

(Source: https://www.academia.edu cited May 2019)

2. Roof shape; there are several roof shapes but in general, used in Indonesia is the gable roof with the end bend upward and is named Ngang Shan.

3. Ornament, the special skill of Chinese to ornamental variety craft dan wood construction is un doubtable. Carving and wood construction as part of the building structure is the characteristic of Chinese buildings. Construction details like roof suspension (Tao Kung), or joint between column and beam, even the roof frame is made beautiful so there is no need to cover it.

4. Colour, the color have a symbolic meaning. In Indonesia, the color red and gold yellow is the most used colors. Red symbolizes fire and blood, connected to wealth and fortune. Also read represents the symbol of virtue, truth, and sincerity, which could be connected to something positive. These colors are usually used in Klenteng.

Chinese, who come to Indonesia are usually from the lower class community such as traders, farmers, and craftsmen. The economic condition makes it hard to fulfill the 4 main characteristics of Chinese Architecture. The Chinese Architecture style is generally used on worship buildings and wealthy merchants. This is usually seen in the trading area, identical to China town because most of the Chinese profession is trading(Soewarno, 2014).

Nowadays, because of city development, road widening in the city center is unavoidable. This causes the loss of Chinese Architectural Style which is the identity of the trading area. Building facades are cut off so the remaining to identify is the gable roof shape of the main building, lies somewhat behind the lot(Soewarno, 2013).

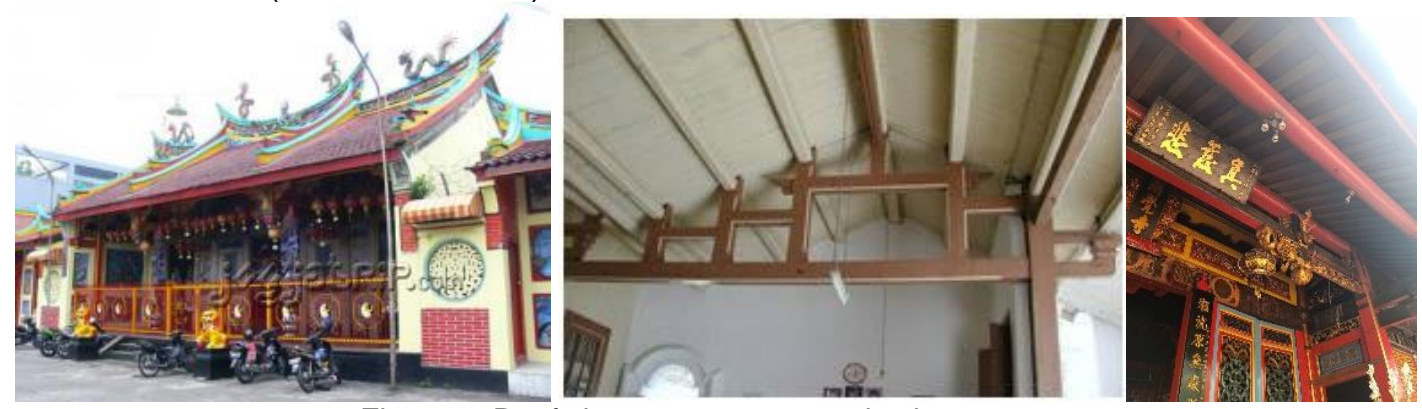

Figure 2: Roof shape, ornament, and color

( source: https://www.academia.edu cited May 2019 \& survey result May 2019)

\subsection{From Tio Kak Sie to Vihara Dewi Welas Asih}

Based on the manuscript from Kasepuhan palace, it was mentioned that Vihara Dewi Welas Asih was built in the year 1559. At the initial establishment of the building, it was named Klententg Tio Kak Sie meaning house for worship or a place to isolate oneself. This Klenteng was built by Chinese immigrant traders and was a worship building for Buddhists(Octavianty, 2017).

The Chinese immigrant came bringing Kongco and Rupang (God and goddess statues) as a safety symbol. Kongco and the statues, later on, were placed in a small building, also used as a worship building. This building lies not far from the beach, facing South or toward the sea. The increase of Chinese people causes the need to expand the building, equipped by various Chinese 
unique ornaments such as dragon statues on the roof, Chinese letters, altar tables, and also added some Kongco and Rupang. At this moment the building space reaches $1600 \mathrm{~m} 2$.

The Gerakan 30 September event brings impact to Klenteng Tio Kak Sie. In the Orde Baru era, everything that has the Chinese connection is forbidden including culture and Chinese traditional believe. Temples are threatened to be closed by force and to have a permit to still operate the temple adopts Sanskrit or Pali names, change into Vihara that is more related to Buddha religion(Amsha, 2018).

Klenteng change into Vihara. Meanwhile, the name of Dewi Welas Asih was taken from one of the Rupang Kwan Im Goddess. The Goddess has compassion or in Javanese means welas asih, therefore this temple was renamed the Wihara Dewi Welas Asih.

After the Orde Baru replaced by Reformation Orde, many Viharas reverted to their original Chinese names and dared to declare themselves to be Klenteng rather than Vihara or call themselves places of worship of Tridharma (TITD): Buddhism, Taoism, and Confucianism.

At present time Vihara Dewi Welas Asih has been established as Cultural Heritage Building (BCB) by Surat Keputusan Wali Kota Cirebon Nomor 19 Tahun 2001; concerning the Protection and Preservation of Regions and Cultural Heritage Buildings in Cirebon City(Binbangkum, 2010). The statue in the Vihara is an object that is still maintained, since the arrival of Chinese people to Java until the present time.

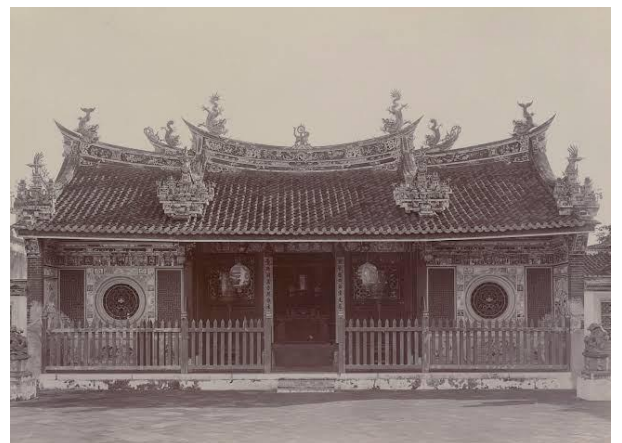

Figure 3: The Previous façade of Klenteng Tio Kak Sie (source: documentation of Wihara Dewi Welas Asih, picture taken May 2019)

\subsection{Adaptation to Cultural Heritage Building}

\section{The Development of Wihara Dewi Welas Asih}

As time went on, Vihara Dewi Welas Asih has been renovated and added building area several times. At present the land area is $1.857 \mathrm{~m} 2$ and the building area is $1.600 \mathrm{~m} 2$ with 2 times development, as follows(Defitrina, Martha; Aji Try Bowo; Purnama, 2019):

Early development. It is estimated that this Klenteng was built in the year 1559 with area $329 \mathrm{~m} 2$ and used only as a worship place

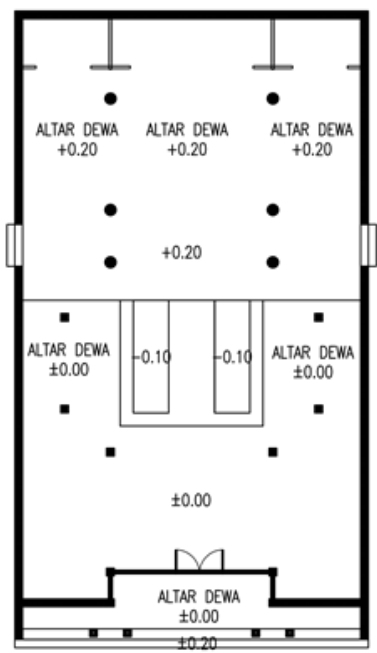

Figure 4: Previous floor plan (survey result, May 2019) 
The first development phase was during the year 1791-1889. In line with the increasing of Chinese migrants, the need for prayer rooms also increased. The $500 \mathrm{~m} 2$ additional building placed at the right side and back yard which was still possible. The additional building used for a prayer room and storage(Defitrina, Martha; Aji Try Bowo; Purnama, 2019)

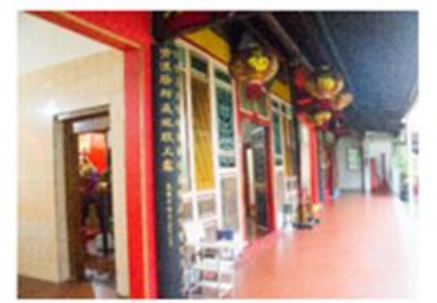

(A)

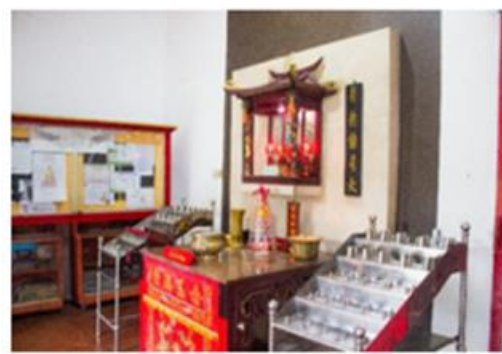

(C)

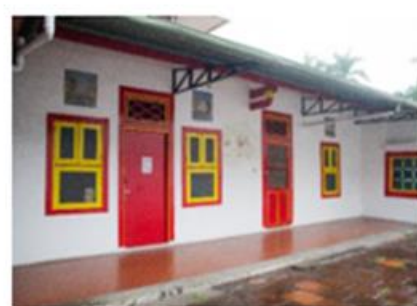

( B )

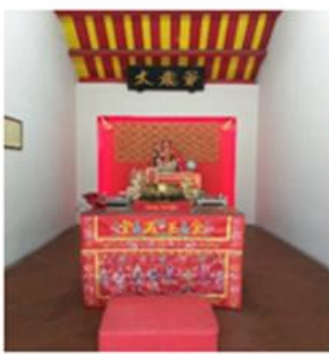

(D)

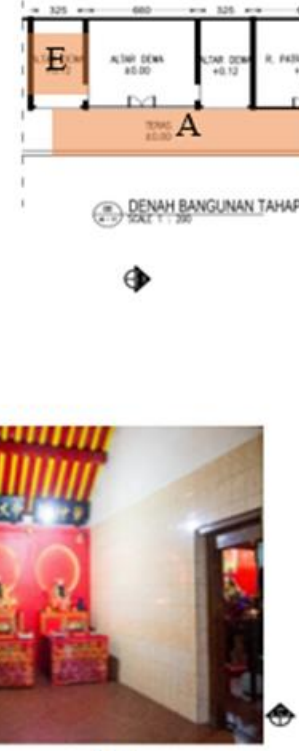

( E)

Figure 5: The first additional building (survey result, May 2019)

The second development phase was in the year 1970. This development phase was the impact of the Orde Baru regime and the possible place to be built was only on the left side and because the area was not so big, the additional building area of $245 \mathrm{~m} 2$ is made into 2 floors.
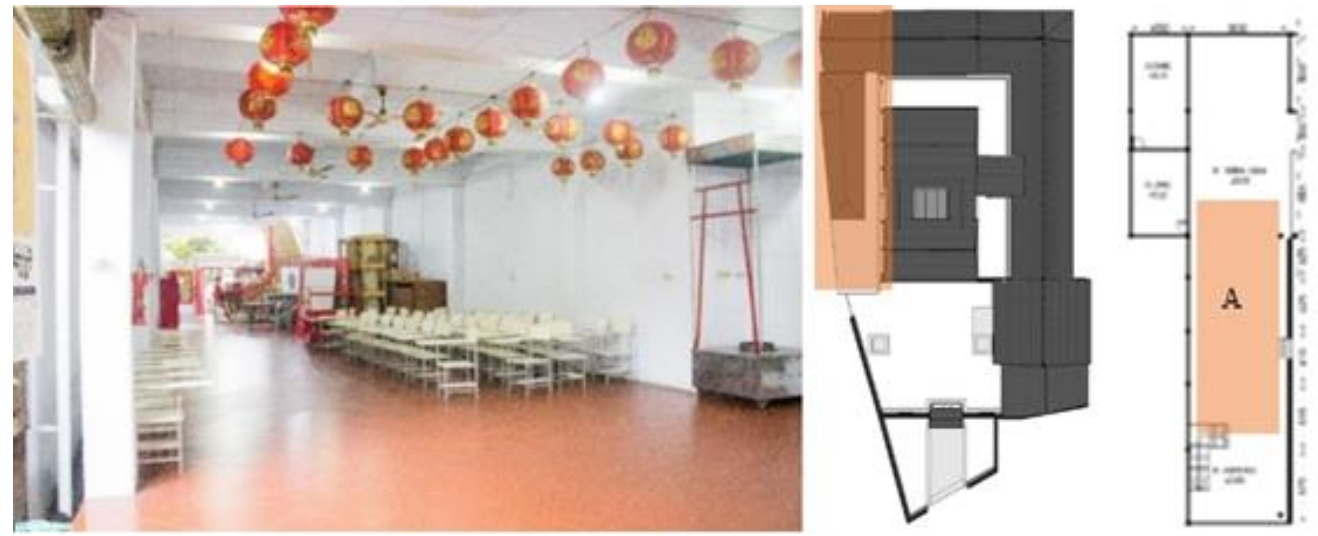

Figure 6: The second additional building (survey result, May 2019) 


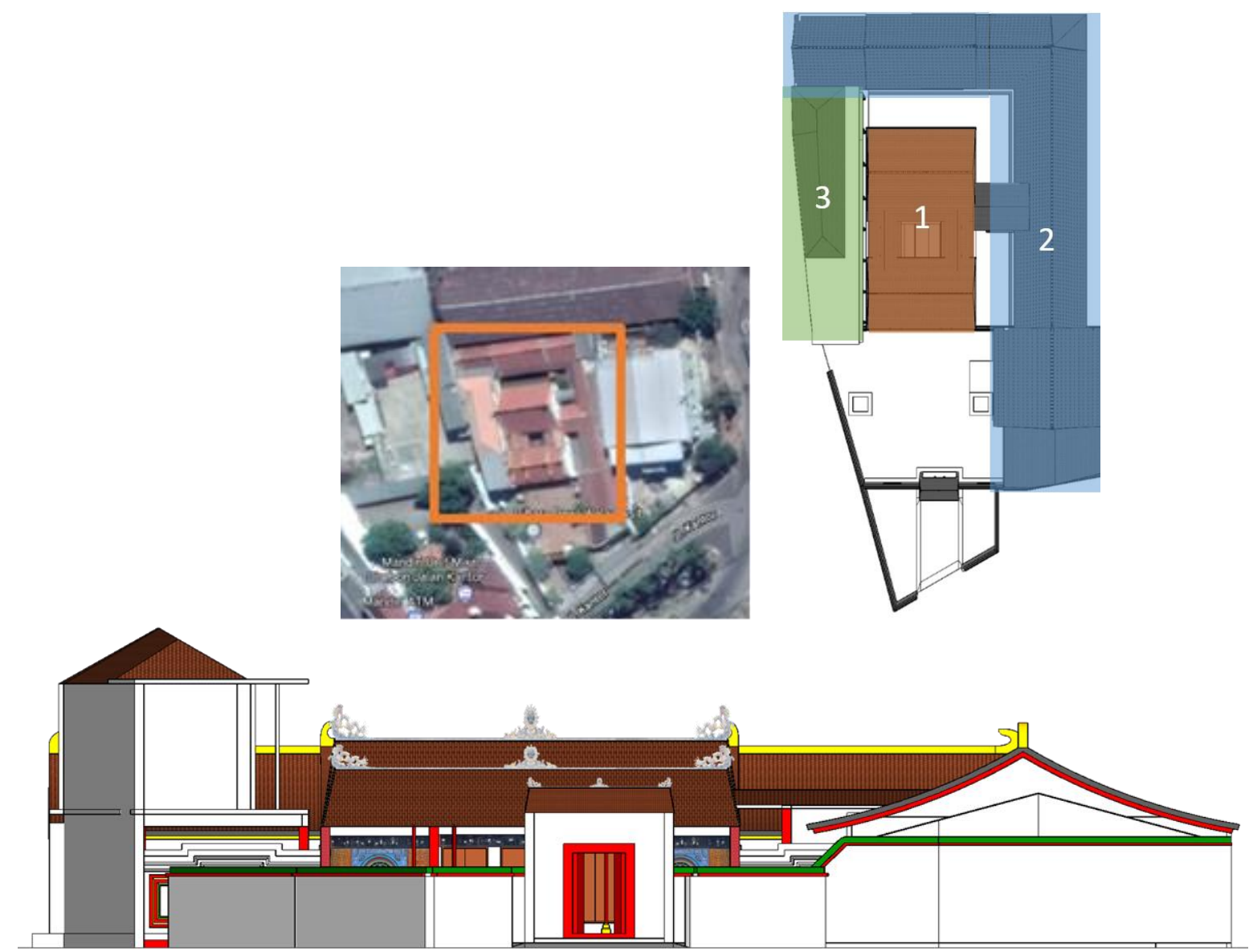

Figure 7: Present site plan and façade of Vihara Dewi Welas Asih (survey result, May 2019)

\subsection{The Adaptation of Architecture Style}

The adaptation of the additional building style to the Vihara's main building is mainly seen in three aspects, namely roof shape, ornament, and color. These three aspects are the easy to recognize special futures of Chinese Architecture(Defitrina, Martha; Aji Try Bowo; Purnama, 2019).

Table 1. Analysis Architecture Style for Key Study Variables

\begin{tabular}{|l|l|l|l|}
\hline \multicolumn{2}{|c|}{ First Period } & Second Period & \multicolumn{1}{c|}{ Third Period } \\
\hline $\begin{array}{l}\text { ROOF } \\
\text { SHAPE }\end{array}$ & $\begin{array}{l}\text { Gable roof with the end } \\
\text { bend upward with tile } \\
\text { cover }\end{array}$ & $\begin{array}{l}\text { Gable roof with the end } \\
\text { bend upward with tile } \\
\text { cover }\end{array}$ & $\begin{array}{l}\text { Shield combined with } \\
\text { flat roof with metal } \\
\text { cover }\end{array}$ \\
\hline ROOF & &
\end{tabular}




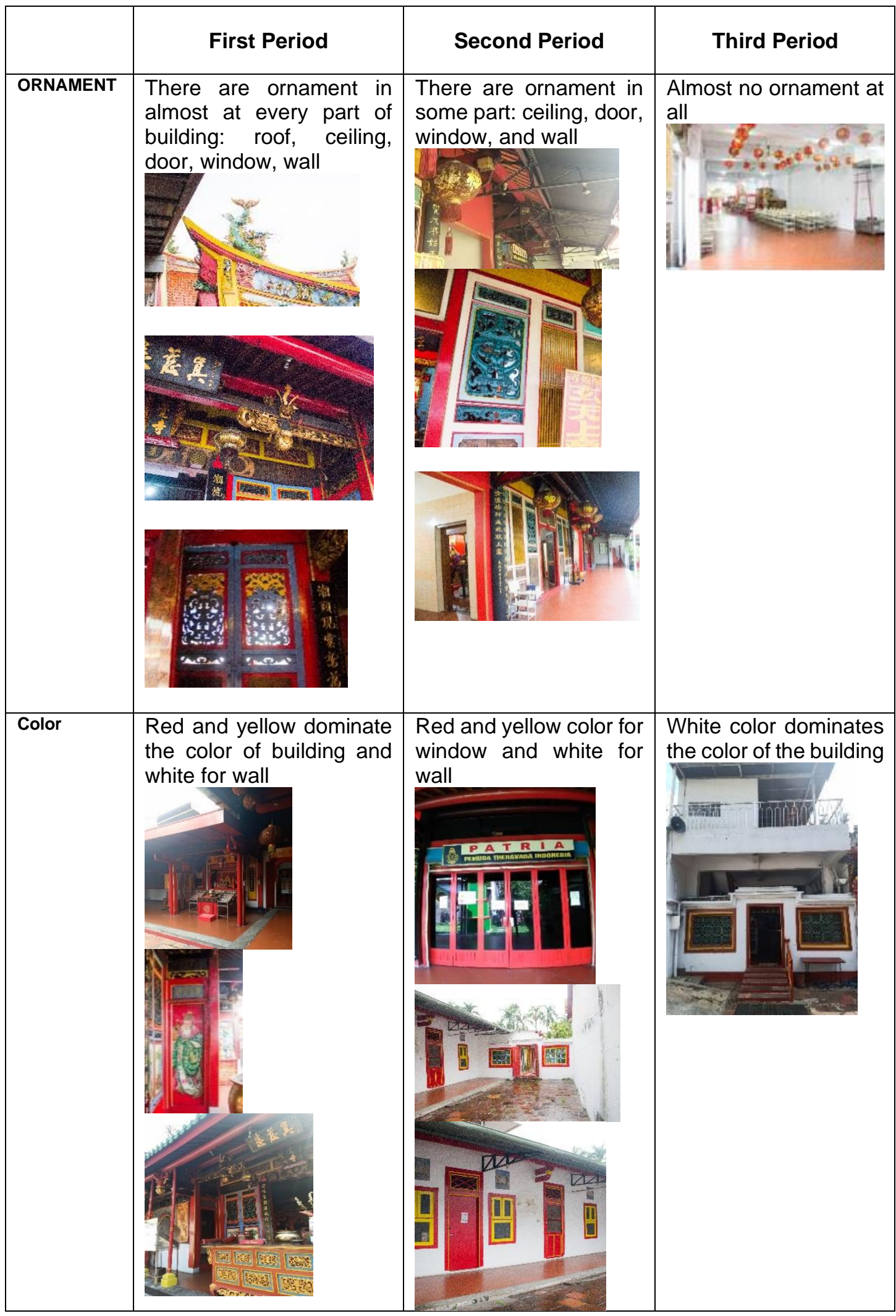

Tio Kak Sie temple was established by the fishing community around 1590. Along with the development of Cirebon city, the coastal area developed into a commercial area. Chinese people who have trade expertise choose to live in this area. This has an impact on the addition of altars and worship spaces for 'Commerce God' and others God at Klenteng Tiao Kak Sie. 
At that time on the right and backside of the building, there was still available empty land which made it possible to expand and add more buildings. The additional building was built in 1790 when Indonesia was still under the Dutch Colonial government. The availability of material still allows additional buildings to use similar building styles and materials with the main building.
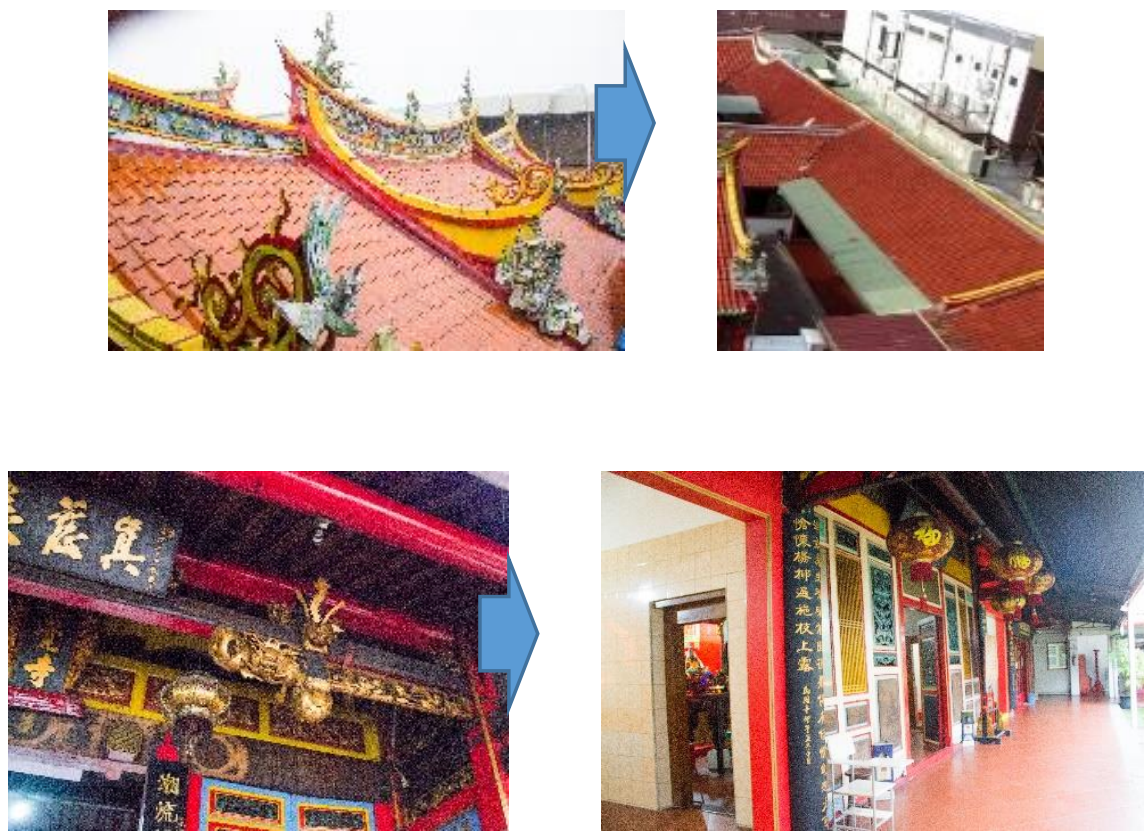

Figure 8: Similar roof model, ornament and color between the Main Building and the first additional building (survey result, May 2019)

Unlike the first expansion, the second additional building was more driven by the socialpolitical condition. In the year 1970, the Orde Baru regime forbid everything that had the Chinese connection and did not admit the Confucianism as a religion but consider it part of Buddhism. Therefore Klenteng hiding behind the name of Vihara so Klenteng Tiao Kak Sie turned into the Vihara Dewi Welas Asih. This political situation reduced the number of Confucian congregations and instead increase the number of Buddhist congregations.

Differences in belief were reflected in the second additional building which was built on the right side of the lot. No red color, no Chinese ornament although the majority of congregations were Chinese descent. The rejection of various activities related to China caused the next generation no longer to follow the belief of their parents. This has an impact on the economic situation of 'Vihara' which is very dependent on donor congregations.

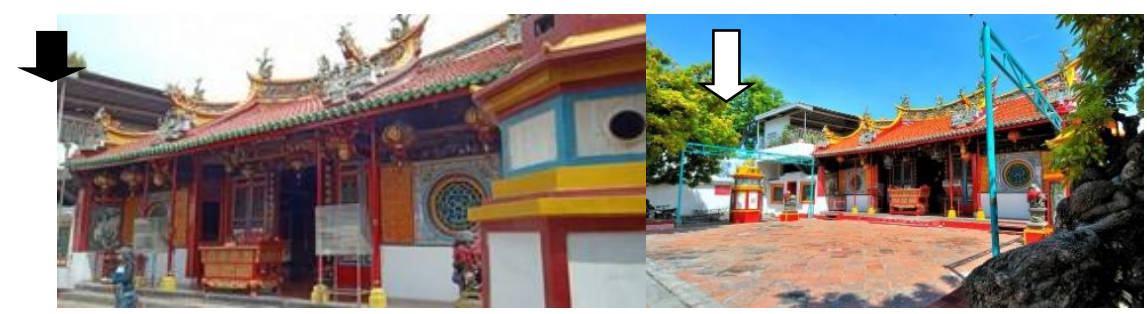

Picture 9: The second additional building at the right side looks different to Main Building (survey result, 2019)

\section{Conclusion}

Brolin in his book Architecture in Context(Brolin, 1980) states that new buildings must adapt to old buildings in their surrounding. Additional buildings around the Vihara Welas Asih which is a cultural heritage building should use a harmonious architectural style. In this case, the first additional building has adapted well but due to the construction distance of 200 years, the use of new materials is unavoidable. 
Unlike the first expansion, the second additional building was built in the 20th century where the same material was not possible to obtain. Besides that, although the function is the same as a place of worship, the different beliefs make it not possible for the second additional building to adapt to the Architecture Style of the main building. This makes the second additional building looks odd standing side by side with the Vihara Dewi Welas Asih, both the architectural style, building shape, and the contrasting colors.

The current problem is how to treat the old material from weathering, mainly due to weather and climate factors. It is recommended to use new materials to protect buildings, such as coatings, paints, and waterproofing to protect especially wooden frames as the main construction. Maintenance of the roof cover is needed because it is the most important part that protects the building and its contents as a cultural heritage.

Intensive maintenance efforts are needed so that the condition of the building, especially the roof structure and ornaments in the main building and the first additional building are well maintained. Therefore a significant amount of funds is needed so that it is expected that routine incentives from the Government and congregations to be able to preserve the Vihara Dewi Welas Asih as worship building and Chinese cultural heritage in the city of Cirebon.

The seriousness of Vihara management, which the majority of Chinese descent, has a great influence on maintenance. They have a moral responsibility for their inheritance so they take care of and maintain optimally. Government regulation that has established the Vihara Dewi Welas Asih as a cultural heritage building helps managers keep trying to preserve the cultural heritage of their ancestors.

\section{References:}

Amsha, A. Q. (2018, February). Inilah Perbedaan Antara Klenteng dan Vihara, Yuk Pahami Biar Tak Bingung Lagi! Tribun Jabar. Retrieved from https://jabar.tribunnews.com/2018/02/16/inilahperbedaan-antara-klenteng-dan-vihara-yuk-pahami-biar-tak-bingung-lagi

Binbangkum, B. R. (2010). Undang-undang no.11 thn 2010 tentang Cagar Budaya.

Brolin, B. C. (1980). Architecture In Context fitting new building with old. New York.

Defitrina, Martha;Aji Try Bowo;Purnama, A. M. B. (2019). Perkembangan Langgam Arsitektur pada Bangunan Klenteng Kwan Im di Cirebon. Institut Teknologi Nasional Bandung-Indonesia.

Kohl, D. G. (1984). Chinese Architecture in the Straits Settlements and Western Malaya: Temples, Kongsis and Houses No Title (First Edit). Kuala Lumpur: Heinemann Asia.

Lia, E. (n.d.). Kisah Niaga Cheng Ho dan Lahirnya Kampung Pecinan Cirebon. Retrieved from https://www.ayobandung.com/read/2019/07/24/58630/kisah-niaga-cheng-ho-dan-lahirnyakampung-pecinan-cirebon

Mengintip Sejarah Vihara Dewi Welas Asih, Klenteng Tertua di Kota CirebonNo Title. (n.d.). Retrieved April 16, 2020, from https://dejabar.id/mengintip-sejarah-vihara-dewi-welas-asihklenteng-tertua-di-kota-cirebon/

Octavianty, A. (2017). Klenteng Tiao Kak Sie Cirebon. Retrieved from https://situsbudaya.id/klenteng-tiao-kak-sie-cirebon/

Soewarno, N. (2013). Kawasan Pusat Kota Sebagai Lingkungan Hunian: Transformasi Arsitektur Hunian Di Kawasan Pusat Kota Kasus: Kawasan Pasar Baru-Bandung. Parahyangan Katolik University.

Soewarno, N. (2014). Transformations of Vernacular Buildings: Chinatown in Bandung City , Indonesia. ISVS E-Journal, 3(1), 42-49. 